\title{
Implementation of Problem-Based Learning and Inquiry (PBL) Learning Methods on Bureaucratic and Political Subjects
}

\author{
Dewi Anggraini ${ }^{1}$, Didi Rahmadi ${ }^{2}$ \\ \{dewianggraini@soc.unand.ac.id ${ }^{1}$ \} \\ ${ }^{1,2}$ Departement of Political Sciences,Universitas Andalas, Padang, Indonesia
}

\begin{abstract}
Bureaucratic and political subjects are grouped into expertise and skill subjects (MKK) and are compulsory subjects at Political Sciences Departement. The learning process of this subjects explain several important topics about bureaucratic and political issues, both internally and externally in context of political relations. This subject is attended by 70 students in the second half semester of 2018/201. The learning process has been conducted using the Student Center Learning (SCL) method with the approach of problem-based learning and Inqury (PBL). students was divided into 7 groups before midterm semester and each group presented their own topics according to the Semester Learning Plan (RPS) subject. furthermore the students were further divided into eight groups with each group consisting of 8-9 people / groups. The student group is further divided in pairs with the composition of 8 groups into 4 paired groups. For example, Groups 1 and 2 will be installed to discuss one lecture topic, with one group as the presenter, who will perform the presentation while one group will respond to the previously specified topic and explained by the presenting group. After the two groups have finished presenting the other group can ask questions, opinions or disclaimers and after that the other group will give an assessment of the course of the presentation and choose the best speaker from both groups. Learning assessment is no longer determined by the student's final outcome, but is seen from the whole process in following this course (attendance, activity in class discussion). The assessment system consists of the midterm exam (25\%) and final Semester exam (25\%) While the assessment of the process consists of individual tasks and presentations (critical thinking ability and logical argument, communication) (25\%) and final tasks in the form of case analysis (technical and analytical skills, teamwork, communication) (15\%). For this semester, the spread of students ranged from 76-95 (C+ to A-), with details as many as 22 students get $\mathrm{A}$ value, 35 students get $\mathrm{A}$-value, 7 students get $\mathrm{B}+$ value, and 5 students get $\mathrm{B}$ value and 1 Student get the $\mathrm{C}+$ value.
\end{abstract}

Keywords: method, learning, student center learning.

\section{Introduction}

Bureaucratic and political subjects are grouped into expertise and skill subjects (MKK) and are compulsory subjects at Political Sciences Departement. This course discusses several important topics concerning bureaucracy and political issues. Both internally and externally in the context of political relations. Internally the discussion begins with a search of theoretical 
conception of bureaucracy in both classic and modern perspectives. In addition, internal discussion is more geared towards the political paradigm that takes place in bureaucracy, including political collective in bureaucracy, imperialism (forms of domination) in bureaucracy, as well as conflicts and domination Political bureaucracy. While externally, the discussion of bureaucratic problems is directed in the context of the public service agent, its relation to the interests of politicians and markets, as well as the political dilemma of bureaucracy in democracy.

Hopefully through this course students are able to understand and explain; Relevant concepts in explaining and answering the problems that exist in the study of the bureaucracy, especially in Indonesia that is associated with the political relations of power. These courses are also expected to produce competency of students, especially in drafting a task and a brief essay so that they are able to write their ideas, related to the topics of subjects contained in the RPS, such as conception of Weberian bureaucracy and classical and modern bureaucracy, paradigm of pluralism in politics and bureacratic politics, the political uses of bureaucracy, politics in buraucracy, bureaucracy versus democracy and representative theory bureaucracy as well as Bureaucracy relations with political parties and parliaments.

Learning achievements in the curriculum of the course include: Mastering the basics of bureaucracy theory/concepts in political relations and developing science in accordance with the development of IPTEKS for the community, uphold the value of Humanity in carrying out tasks based on religion, moral, and ethics, contributes to the improvement of the quality of community life, nationality, country, and progress of civilization based on Pancasila, cooperate and have social sensitivity and Awareness of society and the environment, able to demonstrate independent, quality and measurable performance, able to make appropriate decisions in the context of problem solving in the field of expertise, based on the results of information and data analysis, able to Maintain and develop a network with advisers, colleagues, associates both inside and outside the institution and the stakeholders, able to analyze the political behavior that occurred in the bureaucracy, able to analyse some bureaucracy issues and Politics, able to advocate a bureaucracy reform phenomenon in Indonesia. To achieve these capabilities, the learning process uses primary teaching materials such as textbooks, journals, laws and other rules, as well as lectures for secondary teaching materials using power points, Plano papers and meta plan and audiovisual moves, case study, problem based learning and others that support learning method Student Centered Learning (SCL).

Learning methods applied in the learning process of bureaucracy and politics have not been fully sourced in the SCL method of learning. The learning process still maintains the Teacher Centered Learning (TCL) method. Where, TCL also combined with the SCL method. The percentage is $40 \%$ TCL, where lecturers still give lecture methods at the beginning of the lesson as an introduction to the learning topic and at the end of the lecture as a conclusion of the results between student discussions and 60\% SCL where the material has been Using a much more attractive media such as moving audiovisual, Plano paper, class discussions with SCL-based RPS.

For assessment is divided into two categories, the first, the assessment of results consisting of the midterm exam (25\%) And the final exam of the Semester (30\%). Secondly, assessment of processes consisting of Individual tasks and presentations (quality of work, critical thinking ability and logical arguments, originality and novelty, initiative/participation) $20 \%$, group tasks and presentations (technical capabilities and Analytical, teamwork, communication, originality and novelty, Initiative/participation) $15 \%$ and writing in the mass media related to the topics of the lecture as much as $10 \%$. This course has been conducted in 
the last semester 2017, where the student spreads range from 70-100 (B to the A-). For this semester the student's value spreads from B-A. There are several student issues that are often found during the learning process such as the lack of a student's softskills as well as a lack of students ability to communicate and provide views in each learning meeting Courses and the lack of asking students to write in the mass media. Therefore, in this semester there are several changes in the topic of assessment and changes in process evaluation with an additional $10 \%$ assessment for students whose writings are published in the mass media both local and national.

The assessment of student learning has fully referred to the SCL method where the learning evaluation process is no longer determined by the student's final outcome. Assessment in this course is not only seen from the final exam of the semester, duty, or final exam of the semester but is seen from the whole process in following these courses (attendance, activity in class discussion). Not only in the classroom, the assessment process is also seen from the activities of students who support the strengthening of science such as participating in organizations and other student activities.

\section{Methods}

Related to the study plan for the latest RPS, based on the results of previous RPS evaluation, there is an addition to the topic of discussion for the future study, especially on the discussion of regulation package on the position of bureaucracy Indonesia, such as the ASN $\mathrm{ACT}$ and bureaucracy reform in Indonesia. It will also be added to the discussion of successful strory in the management of bureaucracy in several districts/towns and Nagari/village in West Sumatera. There are several learning plans that want to be applied as an effort to improve learning achievement:

1. Identifying the learning characteristics of students through pretests and Postes implemented before and after the lecture process is implemented to measure the knowledge and ability of students in understanding the topics present in the RPS courses

2. Conduct a study contract based on students ' active participation

3. Designing a classroom atmosphere that can interact with all participants.

4. At the beginning of the lecture, lecturers provide an introduction to the material and throw various issues or cases so that it stimulates students to issue his opinion in the form of class discussions.

5. Open discussions related to learning topics.

For the development of learning methods, the learning team chooses to use problem-based learning and Iquary (PBL). PBL itself is a learning strategy that groups students in small discussion groups. In this group of discussions they are required to study independently by submitting what they get after the developer team gives the topic to be discussed together.

PBL Tutorial is done in various ways, in research this PTK will be discussed model "seven jumps" applied in the University of Andalas, especially in the Faculty of Medicine, but has been modified in such a way that it can be applied On social Humanities Research. The PBL method begins with the awarding of a lecture topic in the RPS to be discussed at each meeting, students are given a handbook containing lecture materials. The PBL implementation steps are as follows: a) Learners are welcome to choose their seats on seats that have been arranged in such a way that makes group discussions easy. b) The student chooses the chairman of the group who will act as the moderator of the discussion, and the notulent to 
record the discussion on the sheet of paper. Role plays for each scenario. The Flip chart or the appropriate whiteboard should be used to record the discussion process. c) At the beginning of the session, one of the students read the topic to all members of the group or each student read the topic themselves. The Seven Jumps stages are as follows: Step 1; Identifying and explaining the unintelligible terms found in the topic of the lecture, the Minutes of records a list of terms that remain unexplainable after the discussion. Step 2; Defining problems or issues to be discussed, students.

May have a different view about the problem, but all must be considered, the clerk noted the list of issues that have been agreed. Step 3; "Brainstorming" is a session to discuss an agreed issue to be discussed. Students discuss possible explanations or assumptions that may explain the problems set out in step 2, using the knowledge they have previously had. Students collaborate using their respective knowledge and identify areas of knowledge that have not been explained correctly or not enough. The scribe records all discussion results. Step 4; Do a review of the discussion in steps 2 and 3. Then set explanations into tentative solutions, which are restructured in the form of schemes. Step 5; Formulating learning objectives, the group reaches consensus on learning objectives, tutors ensure focus learning objectives, achievable, comprehensive, and precise. Step 6; Self-study. All students gather information relating to their respective learning objectives. This step is done outside the PBL tutorial. Lecturers or tutors need to provide sufficient time for students to conduct independent study so that all learning objectives are achieved. Step 7; The group re-gathered for discussion (group discussion). Students share and discuss their independent learning outcomes. Tutor/Cocoordinator evaluates student learning outcomes. The role of the PBL Tutor/Cocoordinator in facilitating the discussion process, is as follows: a) assisting the group's Chairman to maintain group dynamics; b) Ensure the group is able to complete the prescribed learning objectives; c) Tutors may need to take a more active role in the tutorial process to ensure that all students have done their tasks appropriately; D) help suggest the presentation format of independent learning outcomes appropriate for group members; e) Encourage students to evaluate their understanding of the material. Tutors can do this by asking open questions, encouraging students to ask, to explain the material in their own words, with drawings and schemes; and f) Provide feedback on students regarding their participation in the tutorial process and about achieving learning objectives.

The Learning achievement assessment refers to the entire learning process. Surely the assessment process is the value of study evaluation that is systematically acquired both cognitive, psychomotor, and affective from the beginning and end of learning. The assessment plan adopted the pedagogy learning of Paulo Freire which focuses on the overall participation process.

The curriculum used in this course has been using the KKNI curriculum, in which the development of the KKNI curriculum in the study program has been based on the graduate profile. In the political science department, there are 5 (five) graduates ' profiles, namely academics, political practitioners, general election executives, bureaucrats and NGOS.

The development of learning technology is largely still using various learning media that has been provided by the university, such as using laptops, Infokus and audio visuals, but it remains modified by the developer team in making Learning technology that follows the flow of student development, the developer team also utilizes WA media as a medium of student interaction with lecturers and their interneighbors in the learning process. In using this WAG, both materials from lecturers and presentation materials from students must be uploaded to WAG the day before the face-to-face lecture is done, so there is time together to read the 
ingredients for the next lecture, and this Students ' understanding of the materials to be taught at the next meeting.

The assessment in political and bureaucracy courses is not only based on the standard of results, but also based on process standards, there is even additional value/point for students who can write in mass media both local and national related to Topics contained in the RPS that have been shared previously.

\section{Results and Discussion}

Bureaucracy and Politics courses taught in the second semester of the 2018/2019 school year were attended by 70 students who were included in the local political concentration. The learning process of this course has been carried out using the Student Center Learning (SCL) method with the problem-based learning (PBL) approach by combining also with the Teacher Center Learning (TCL) method on certain topics. In addition, in the learning process also uses primary teaching materials such as textbooks, journals, laws and other rules. While for secondary teaching materials use power points, flipcharts and meta plans as well as mobile audiovisuals, case studies and others. After Mid Semester, students are divided into small groups with a total of 8 groups, in which one group ranges from 8-9 students. The student groups are further divided in pairs, so from 8 groups they are made into 4 groups in pairs. For example, groups 1 and 2 will be paired to discuss a lecture topic, with one group as a presenter, who will make presentations in a paired group and another group will be a respondent to an agreed topic. After the two groups have finished doing the presentation, the other group may ask questions, opinions or arguments, and after that the groups outside the two groups will give an assessment of the presentation as well as selecting the best speakers from both groups. Likewise for the next meeting the same process will be carried out.

The assessment of student learning outcomes has fully referred to the SCL method where the process of providing learning evaluations is no longer determined by the student's final results. The assessment in this course is not only seen from the final results of the midterm, assignments, or final examinations, but it is seen from the whole process in following this course (attendance, activeness in class discussions). Not only in the classroom, the assessment process is also seen from student activities that support scientific strengthening such as participating in organizing and other student activities.

The assessment system consists of the Midterm Examination (25\%) and the Final Examination Semester (25\%) while the assessment process consists of personal and individual assignments and presentations (critical thinking skills and logical argumentation, teamwork, communication) (25\%) and final project in the form of case analysis (technical and analytical skills, teamwork, communication) (15\%). In the previous semester that had been implemented, the distribution of student grades ranged from 70-100 (B-A).

For this second semester, the distribution of student scores ranges from 76-95 $(\mathrm{C}++-\mathrm{A})$, with details of 22 people getting an A, 35 people getting an A-, 7 students getting a B + value, and 5 students getting a value $\mathrm{B}$. And 1 student gets a $\mathrm{C}+$ grade. In addition, there are some students who take the theme of the proposal relating to several topics in the RPS of this course. Of the several topics contained in the RPS of this course, the topics most sought after by students regarding bureaucratic reform and bureaucratic pathology issues. This study received many responses from the results of discussions with students compared to other topics.

There are several methods given in the learning process of Bureaucracy and Politics courses, namely: Identifying student learning characteristics through pre-test and post-test that 
is conducted before and after the lecture process is carried out to measure students' knowledge and ability in understanding topics in the course RPS , make a learning contract based on active student participation, design a classroom atmosphere that can interact with all class participants, at the beginning of the lecture, the lecturer gives introductory material and throws a variety of issues or cases so as to stimulate students to express their opinions in the form of class discussion and open as widely as possible discussion related to the topic of learning.

In the learning process there are some student problems that are often found such as the lack of soft skills owned by students and the lack of students' ability to communicate and provide insight at each learning meeting. And the obstacle most students do not know or do not understand the updated studies of political and bureaucratic developments, especially regarding formal studies of bureaucratic development in Indonesia.

\section{Conclusion}

The application of the Student Centered Learning (SCL) learning method with the Problem Based Learning and Inqury (PBL) approach in the learning process of Politics and Bureaucracy courses can improve student learning outcomes and achievements, of the 70 students taking this course, none of them failed lectures, in fact there were some students who were interested in raising the title of the research related to several topics contained in the RPS of this course. Improvement of student soft skills can develop with the application of the SCL method, as evidenced by the large number of student responses during class discussions, especially related to communication skills, critical and analytical thinking and the ability to solve problems when given a case to be solved in groups and individually.

\section{References}

[1] Afrizal, dkk. 2014. Panduan Praktis Pelaksanaan Student Centered Learning (SCL) : Meningkatkan Interaksi Mahasiswa dan Dosen Dalam pembelajaran. LP3M Unand

[2] Arikunto. 2006. Penelitian Tindakan Kelas. Jakarta : Bumi Aksara

[3] Muhason, A. 2009. Peningkatan Minat Belajar dan Pemahaman Mahasiswa Melalui Penerapan Problem Based Leraning. Jurnal Kependidikan, Vol 39. No 2. PP 171-182

[4] Sanjaya, W. 2006. Strategi Pembelajaran. Jakarta : Kencana Prenada Media Grup

[5] Sudarman. 2007. Problem Based Learning : Suatu Model Pembelajaran Untuk Mengembangkan dan Meningkatkan Kemampuan Memecahkan Masalah. Jurnal Pendidikan Inovatif, Vol 2. No 2.PP 68-73

[6] Trianto. 2009. Mendesain Model Pembelajaran Inovatif-Progresif. Surabaya : Kenana Prenada Media Grup 